\title{
Factors associated with beliefs about adherence to non-pharmacological treatment of patients with heart failure*
}

\author{
FATORES ASSOCIADOS ÀS CRENÇAS SOBRE ADESÃO AO TRATAMENTO NÃO \\ MEDICAMENTOSO DE PACIENTES COM INSUFICIÊNCIA CARDÍACA
}

\section{FACTORES ASOCIADOS A LAS CREENCIAS SOBRE LA ADHERENCIA AL TRATAMIENTO NO FARMACOLÓGICO DE PACIENTES CON INSUFICIENCIA CARDÍACA}

\author{
Izabel Cristina Ribeiro da Silva Saccomann', Fernanda Aparecida Cintra², \\ Maria Cecília Bueno Jayme Gallani ${ }^{3}$
}

\begin{abstract}
This study aimed at assessing beliefs about the benefits and barriers to adherence to daily self-monitoring of weight/edema in patients with heart failure, and the influence of demographic and clinical variables on those beliefs. 105 patients were interviewed. The mean of the subscales Benefits and Barriers were 20.2 ( \pm 5.7) and 30.1 $( \pm 7.1)$, respectively. Patients perceived that adherence to daily self-monitoring of weight/edema could keep them healthy, improve their quality of life and decrease the chances of readmission. Approximately half of patients $(46.7 \%)$ reported forgetting this measure. Those who controlled weight once a month were more likely to have barriers to adherence (OR $=6.6$; IC 95\% 1.9-13.8; $p=0.01$ ), showing this measure to be the main factor related to perceived barriers. Education in health can contribute with the development of strategies aimed at lowering barriers and increasing benefits of this control.
\end{abstract}

\section{RESUMO}

Este estudo teve como objetivos avaliar as crenças relativas aos benefícios e às barreiras para a adesão ao automonitoramento diário do peso/edema em pacientes com insuficiência cardíaca e verificar a influência das variáveis sociodemográficas e clínicas sobre essas crenças. Foram entrevistados 105 pacientes. A média das subescalas Benefícios e Barreiras foram 20,2 $( \pm 5,7)$ e $30,1( \pm 7,1)$, respectivamente. Os pacientes percebiam que a adesão ao automonitoramento diário do peso/edema poderia mantê-los saudáveis, melhorar a qualidade de vida e diminuir as chances de reinternação. Aproximadamente a metade $(46,7 \%)$ relatou esquecimento dessa medida. Os que controlavam peso uma vez por mês apresentaram maior chance de barreiras à adesão ( $O R=6,6$; IC 95\% 1,9-13,8; $p=0,01$ ), revelando essa medida como o principal fator relacionado às barreiras percebidas. $\mathrm{A}$ educação em saúde pode contribuir para o desenvolvimento de estratégias direcionadas a diminuição das barreiras e aumento dos benefícios desse controle.

\section{RESUMEN}

Este estudio tuvo como objetivos evaluar las creencias respecto a los beneficios y las barreras para la adherencia a la automonitorización diaria del peso/edema en los pacientes con insuficiencia cardíaca e identificar la influencia de variables sociodemográficas y clínicas sobres estas creencias. Se entrevistaron 105 pacientes. La puntuación promedio de las sub-escalas Beneficios y Barreras fueron 20,2 $( \pm 5,7)$ y $30,1( \pm 7,1)$, respectivamente. Los pacientes percibían que la adherencia a la auto-monitorización de peso/edema diario podría mantenerlos saludables, mejorar la calidad de vida y reducir las posibilidades de re-hospitalización. Aproximadamente la mitad de ellos $(46,7 \%)$ informaron haber olvidado efectuar este control. Los pacientes que controlaban su peso una vez al mes presentaban más oportunidades de barreras a la adherencia (OR $=6,6$, IC $95 \%$ $1,9-13,8, p=0,01)$, siendo esa medida el principal factor con relación a las barreras percibidas. La educación para la salud puede contribuir al desarrollo de estrategias dirigidas a la reducción de las barreras y ampliar los beneficios de este control.

\section{DESCRIPTORES \\ Insuficiencia cardíaca \\ Cumplimiento de la medicación \\ Cooperación del paciente \\ Manejo de la enfermedad \\ Atención de enfermería}

\author{
DESCRITORES \\ Adesão à medicação \\ Cooperação do pacient \\ Cuidados de enfermagem
}

\footnotetext{
* Extracted of the thesis "Educação em saúde na adesão ao tratamento e na qualidade de vida em portadores de insuficiência cardíaca", Post-Graduation Nursing Program, Faculdade de Enfermagem, Universidade Estadual de Campinas, 2012. ${ }^{1}$ Nurse. Assistant Professor, Departamento de Enfermagem, Faculdade de Ciências Médicas, Pontifícia Universidade Católica de São Paulo, Sorocaba, SP, Brazil. isaccomann@pucsp.br ${ }^{2}$ Nurse. Associate Professor, Faculdade de Enfermagem, Universidade Estadual de Campinas, Campinas, SP, Brazil. fernanda@fcm.unicamp.br ${ }^{3}$ Nurse. Full Professor, Faculdade de
} Enfermagem, Universidade Estadual de Campinas, Campinas, SP, Brazil. maria-cecilia.gallani@fsi.ulaval.ca 


\section{INTRODUCTION}

Heart failure (HF) represents a challenge to the health care team and is one of the leading causes of hospitalization in the global scenario(1). Among these causes stand out the lack of non-pharmacological measures, poor adherence to drug treatment and patients' inability to identify predictive signs and symptoms of disease decompensation.

The prognosis of HF patients depends not only on drug therapy, but also on a non-pharmacological approach ${ }^{(2)}$. Adherence to treatment is relevant for the control of symptoms and disease progression and is directly related to complex treatment regimens and diet restrictions of salt and fluids. Studies show that rates of non-adherence to non-pharmacological treatment are high (between 50 and $80 \%)^{(3)}$ and are related to lifestyle changes, namely: restriction of fluid and sodium in the diet, daily weight control and physical activity ${ }^{(4)}$.

Among the major limitations for adherence, the ignorance stands out, as well as the lack of association between what is aprehended by the patient and the outcome of the corresponding behavior. In other words, patients with HF understand that a low-salt diet is important to control the disease, but this information does not always lead them to relate the excess of salt in the diet to water retention and weight gain, which may result in clinical decompensation and subsequent hospital readmission ${ }^{(4-5)}$. Body weight variations greater than $1 \mathrm{~kg} /$ day can be attributed to water retention and indicate onset of worsening $\mathrm{HF}^{(6)}$.

Among the specific behaviors of non-pharmacological treatment of $\mathrm{HF}$, the following are recommended: daily monitoring of weight and edema, physical activity and restriction of sodium in the $\operatorname{diet}^{(7)}$. Despite the relevance of these measures, weight control is the type of care less known by patients ${ }^{\left({ }^{8}\right)}$. However, the literature reveals that the perception of benefits and barriers to a behavior can be changed, with improvement of adherence behavior ${ }^{(9)}$. The nurse plays an important role in the optimization of non-pharmacological recommendations.

Considering that changes in weight are directly related to fluid retention and appropriate use of prescription diuretics, and that lack of adherence to control of this measure may decompensate the clinical status of patients with HF, this study aimed to evaluate the beliefs concerning the benefits and barriers perceived to adherence to daily self-monitoring of weight and edema in patients with HF and also the influence of sociodemographic and clinical variables on these beliefs.

\section{METHOD}

This is a cross-sectional study of broader experimental investigation which evaluated the effect of an educational intervention on pharmacological and non-pharmacological adherence of patients with HF in the outpatient followup of Geriatrics and Cardiology at a university hospital in the State of São Paulo.

The sample consisted of 105 subjects of both genders, aged 50 years or older. This age group was chosen because of the increased prevalence of HF. The subjects met the following inclusion criteria: 1) outpatient follow-up for at least three months (minimum period necessary to run tests of clinical characterization); 2) continuous use of diuretics and 3) ability to understand and communicate. Patients with psychiatric disorders and those with a recent history of acute cardiovascular events (myocardial infarction or unstable angina in the three months prior to data collection) were excluded.

\section{Data collection}

The data collection period was between August 2010 and April 2011. On the date of the medical appointment, patients were invited to take part in the study and explained about its objectives and development. After agreeing, all subjects signed a consent form. The study was approved by the local Committee of Ethics in Research under no 1242/2010.

Data were obtained prior the medical appointment in a private place through individual interviews in which were applied the instruments described below. The information for clinical characterization was extracted from the medical records of patients.

\section{Instruments for data collection}

Sociodemographic and clinical characterization: it contains information regarding name, gender, age, race, origin, marital status, education, work status, with whom one lives and monthly income. It also contains the following clinical characterization data: time since diagnosis, etiology of heart disease that caused HF, comorbidities, functional class according to the New York Heart Association (CF NYHA), left ventricle ejection fraction (LVEF), systolic and diastolic dysfunction, symptoms (dyspnea, fatigue, edema, angina and palpitations), access to a body weight scales and weight control.

Beliefs about Self-monitoring Compliance Scale (BSMCS): culturally adapted into Brazilian Portuguese ${ }^{(10)}$, the scale consists of 18 items with five-point scores ranging from 1 (strongly disagree) to 5 (totally agree). It is intended to measurse the perceived benefits and barriers to adherence to the behavior of daily self-monitoring of weight and edema. Six items measure the benefits to adherence and 12 the barriers to adherence. The analysis of the instrument gives a total score for each subscale, adding the scores obtained on each item. The score of the Benefits subscales varies between 6 and 30 and the higher the score, the greater the perceived benefits. The score of the Barriers subscale varies between 12 and 60 and the higher the score, the higher the perceived barriers. In this 
study, the internal consistency assessed by Cronbach's alpha showed $\alpha=0.70$ for the Benefits subscale and $\alpha=0.50$ for the Barriers subscale.

\section{Data analysis}

Data were analyzed using the SAS (System for Windows Version 9.0). All the variables were subjected to descriptive analysis. The Spearman correlation coefficient was used to analyze the correlation between the scale of beliefs and the sociodemographic and clinical variables. The gender variable was transformed into a dummy variable. The logistic regression analysis was used to assess the association between the dependent variable (perceived benefits and barriers to the weight/edema self-monitoring) and the set of independent variables: sociodemographic and clinical. For this analysis, the dependent variable was treated as a categorical variable, in which the response variable was dichotomized. It was adopted a $5 \%$ level of statistical significance.

\section{RESULTS}

The sample consisted of 105 patients with HF, predominantly white, mean age of 66.1 years $( \pm 9.4)$. The majority was married or living in a consensual union (66.7\%), retired (75.2\%), with up to four years of study $(79.0 \%)$ and monthly family income of less than two minimum wages (82.9\%). The most evident etiology was hypertension (52.3\%) followed by ischemia (27.7\%). The most frequent comorbidities were: severe hypertension (77.1\%) and diabetes mellitus (25.7\%). Most patients were in class II, according to the NYHA criteria (58.1\%). As for weight control, most reported to check it only once a month (47.6\%) (Table1).

\section{Beliefs regarding the perceived benefits and barriers to adherence to daily self-monitoring of weight and edema}

The mean score of the Benefits subscale was 20.2 ( \pm 5.7) and of the Barriers subscale was 30.1 ( \pm 7.1), indicating that patients perceived fewer barriers and more benefits in relation to self-monitoring of weight and edema (Table 2).

The beliefs in relation to the perceived benefits with higher agreement among patients were: checking the swelling of my feet and my legs will keep me healthy, checking the swelling of my feet and my legs will improve my quality of life, and when I weigh myself, I do not care much about my heart disease. Although patients recognize that checking the weight lessens the chances of readmission almost half $(46.7 \%)$ reported forgetting that measure.

The beliefs in relation to the perceived barriers with higher agreement among patients were: I do not have a scales at home to weigh myself, checking the swelling of my feet and my legs is unpleasant and I forget to weigh myself every day.
Table 1 - Sociodemographic and clinical characteristics of patients with HF - Sorocaba, SP, 2011

\begin{tabular}{lll}
\hline $\begin{array}{l}\text { Sociodemographic } \\
\text { Characteristics }\end{array}$ & Mean (sd) & N (\%) \\
\hline Age (years) & $66.1(9.4)$ & \\
$\leq 60$ & & $26(24.8)$ \\
$>60 \leq 75$ & $66(62.9)$ \\
$>75$ & $13(12.4)$ \\
Gender & \\
Female & $56(53.3)$ \\
$\quad$ Male & & $49(46.7)$ \\
Color/ethnicity & \\
$\quad$ White & & $80(76.2)$ \\
$\quad$ Not white & $25(23.8)$ \\
Marital Status & \\
$\quad$ Married & & $70(66.6)$ \\
$\quad$ Not married & $35(33.3)$ \\
Work status & & \\
$\quad$ Retired & & $79(75.2)$ \\
Employed & & $12(11.4)$ \\
$\quad$ Without income & & \\
Education (years of study) & & \\
Income (minimum wage) & & \\
\hline
\end{tabular}

Clinical characteristics

\begin{tabular}{lc}
\hline $\begin{array}{l}\text { Time with HF (years) } \\
\text { Etiology }\end{array}$ & $9.9(7.9)$ \\
Hipertension & $55(52.3)$ \\
Coronary disease & $29(27.7)$ \\
Chagas disease & $13(12.4)$ \\
Cardiomyopathy & $08(7.6)$ \\
Functional Class (New York & \\
Heart Association) & \\
CF I & $19(18.1)$ \\
CF II & $61(58.1)$ \\
CF III/IV & $25(23.8)$
\end{tabular}

Left Ventricle Ejection Fraction $\quad 51.0(13.5)$

\begin{tabular}{|c|c|c|}
\hline Normal ( $\geq 50 \%)$ & & $60(57.1)$ \\
\hline Lowered $(<50 \%)$ & & $45(42.9)$ \\
\hline Comorbidities & $2.3(1.8)$ & \\
\hline 1 & & $54(51.4)$ \\
\hline 2 & & $37(35.2)$ \\
\hline$\geq 3$ & & $14(13.3)$ \\
\hline \multicolumn{3}{|l|}{ Diuretics used } \\
\hline Furosemide & & $72(68.6)$ \\
\hline Hydrochlorothiazide & & $46(43.8)$ \\
\hline Spironolactone & & $29(27.6)$ \\
\hline
\end{tabular}

Average number of diuretics used $1.4(0.5)$

Weight control

1x/week $14(13.3)$

Up to $3 \mathrm{x} /$ week $\quad 05(4.8)$

$1 \mathrm{x} /$ month $\quad 50$ (47.6)

Only on medical appointments $36(34.6)$

Note: $(n=105)$ 
Table 2 - Scores of the subscales Benefits and Barriers perceived to the self-monitoring of weight and edema - Sorocaba, SP, 2011

\begin{tabular}{|c|c|c|c|}
\hline BSMCS* & Média (dp) $\dagger$ & Md \$ & Mín/Máx§ \\
\hline \multicolumn{4}{|l|}{ Benefits } \\
\hline 3. Checking my weight every day will keep me healthy & $2.9(1.6)$ & 3 & $1-5$ \\
\hline 5. Checking my weight every day will improve my quality of life & $3.0(1.7)$ & 3 & $1-5$ \\
\hline 11. When I weigh myself I do not care much about my heart disease & $3.4(1.6)$ & 4 & $1-5$ \\
\hline 15. Checking the swelling of my feet and my legs will improve my quality of life & $3.6(1.4)$ & 4 & $1-5$ \\
\hline 16. If I weigh myself every day, I reduce my chances of being admitted & $3.3(1.5)$ & 3 & $1-5$ \\
\hline 17. Checking the swelling of my feet and my legs will keep me healthy & $3.8(1.4)$ & 4 & $1-5$ \\
\hline Total & $20.2(5.7)$ & 21 & $6-30$ \\
\hline \multicolumn{4}{|l|}{ Barriers } \\
\hline 1. Checking the swelling of my feet and my legs is unpleasant & $3.2(1.7)$ & 4 & $1-5$ \\
\hline 2. It takes a long time to weigh myself every day & $2.5(1.6)$ & 2 & $1-5$ \\
\hline 4. Checking the swelling of my feet and my legs takes a long time & $1.5(0.9)$ & 1 & $1-5$ \\
\hline 6. Checking my weight every day makes me worried about my disease & $2.7(1.7)$ & 2 & $1-5$ \\
\hline $\begin{array}{l}\text { 7. Checking the swelling of my feet and my legs every day makes me worried about my } \\
\text { disease }\end{array}$ & $2.9(1.7)$ & 3 & $1-5$ \\
\hline 8. I do not know how to check the swelling of my feet and legs & $1.8(1.3)$ & 1 & $1-5$ \\
\hline 9. I do not have a scales at home to weigh myself & $4.3(1.3)$ & 5 & $1-5$ \\
\hline 10. It is unpleasant to weigh myself & $2.5(1.7)$ & 2 & $1-5$ \\
\hline 12. I do not know how to use the scales to weigh myself & $1.6(1.2)$ & 1 & $1-5$ \\
\hline 13. I forget to weigh myself every day & $3.1(1.7)$ & 3 & $1-5$ \\
\hline 14. I cannot see the numbers on the scales to weigh myself & $1.6(1.2)$ & 1 & $1-5$ \\
\hline 18. I forget to check the swelling of my feet and my legs every day & $2.6(1.7)$ & 2 & $1-5$ \\
\hline Total & $30.1(7.1)$ & 29 & $12-60$ \\
\hline
\end{tabular}

* BSMCS: Beliefs about Self-monitoring Compliance Scale; †sd: standard deviation; $¥$ Md= Median;

$\S \mathrm{Min} / \mathrm{Max}$ : minimum and maximum variation

Note: $(n=105)$

\section{Correlation between sociodemographic/clinical variables and health beliefs}

The correlation between sociodemographic and clinical variables and health beliefs is presented in table 3. There was a positive correlation between the Benefits subscale and education, showing that the higher the education, the more the patient perceives the benefits of selfmonitoring weight and edema.

The Barriers subscale showed positive correlation with gender and weight verification, a finding that calls attention because women perceived more barriers to control of weight and edema. Patients who checked the weight less often also perceived more barriers to this self-care. It is also noteworthy the negative correlation between the Barriers subscale, education and comorbidities, i.e., the lower the level of education and number of comorbidities, the more the patient perceives verification of weight and edema as a barrier.

The analysis of factors associated with beliefs about adherence to self-monitoring of weight and edema was performed by logistic regression analysis, including the following as independent variables: gender, age, education, income, time with HF, comorbidities, FC NYHA, LVEF, symptoms and weight control. After eliminating the variables that were not significant (stepwise selection) the final result of the logistic model showed weight control as the only variable that influenced the model. In other words, patients who control their weight once a month are more likely to present barriers to adherence to self-monitoring of weight and edema (OR=6.6; IC 95\% 1.9-13.8; $p=0.01)$.

Table 3 -Correlation between the scale of beliefs related to health and sociodemographic and clinical variables - Sorocaba, SP, 2011

\begin{tabular}{|c|c|c|c|c|c|c|c|c|c|c|}
\hline & Age & Gender & Education & Income & $\begin{array}{c}\text { Time with } \\
\text { HF }\end{array}$ & Comorbidities & FC\# & LVEF§ & Symptoms & $\begin{array}{l}\text { Weight } \\
\text { control }\end{array}$ \\
\hline BSMCS* & $\mathrm{r} * *$ & $\mathrm{r}$ & $\mathrm{R}$ & $\mathrm{r}$ & $\mathrm{r}$ & $\mathrm{r}$ & $\mathrm{r}$ & $\mathrm{r}$ & $\mathrm{r}$ & $\mathrm{R}$ \\
\hline Benefits & $\begin{array}{l}0.063 \\
(0.26)\end{array}$ & $\begin{array}{l}0.003 \\
(0.49)\end{array}$ & $\begin{array}{l}0.221 \\
(0.01)\end{array}$ & $\begin{array}{c}- \\
0.001 \\
(0.49)\end{array}$ & $\begin{array}{c}- \\
0.018 \\
(0.43)\end{array}$ & $\begin{array}{c}-0.064 \\
(0.26)\end{array}$ & $\begin{array}{c}- \\
0.039 \\
(0.35)\end{array}$ & $\begin{array}{l}0.049 \\
(0.30)\end{array}$ & $\begin{array}{l}-0.022 \\
(0.41)\end{array}$ & $\begin{array}{l}0.019 \\
(0.42)\end{array}$ \\
\hline Barriers & $\begin{array}{c}-0.054 \\
(0.29)\end{array}$ & $\begin{array}{l}0.158 \\
(0.05)\end{array}$ & $\begin{array}{r}-0.238 \\
(0.00)\end{array}$ & $\begin{array}{c}- \\
0.047 \\
(0.32)\end{array}$ & $\begin{array}{l}0.003 \\
(0.49)\end{array}$ & $\begin{array}{l}-0.190 \\
(0.03)\end{array}$ & $\begin{array}{l}0.079 \\
(0.20)\end{array}$ & $\begin{array}{l}0.003 \\
(0.48)\end{array}$ & $\begin{array}{l}0.079 \\
(0.21)\end{array}$ & $\begin{array}{l}0.245 \\
(0.00)\end{array}$ \\
\hline
\end{tabular}

${ }^{*}$ BSMCS: Beliefs about Self-monitoring Compliance Scale; ${ }^{\star *}$ r: Spearman correlation coefficient and the respective p-value; \# FC NYHA: Functional Class according to the New York Heart Association; § LVEF: left ventricle ejection fraction. Note: $(n=105)$ 


\section{DISCUSSION}

This study showed that a great part of patients (47.6\%) checked their own body weight once a month, $13.3 \%$ checked it once a week and only $4.8 \%$ did it up to three times a week. Most did not have scales at home, which may have contributed to poor adherence to this measure. Having a scales in the household facilitates the establishment of a weight control routine ${ }^{(11-12)}$, and may represent a crucial factor for the daily weight control in patients with $\mathrm{HF}^{(13)}$. Furthermore, the presence of significant positive correlation between weight control and the perceived Barriers subscale may explain the results obtained. Patients who checked their weight less often also perceived more barriers to this self-care.

Moreover, the rates of adherence to daily weight control showed high variability, ranging between 12 and $42 \%{ }^{(14)}$. A large proportion of patients (77\%) did not report their weight gain to their doctors and $50 \%$ did not consider a sudden weight gain to be important ${ }^{(15)}$. One study showed that only $46 \%$ of patients received instructions about the importance of daily weight control ${ }^{(16)}$.

A small percentage of patients with HF (5\%) recognize weight gain as a sign for hospital admission, with average waiting tolerance of between three to seven days before seeking medical assistance ${ }^{(14)}$. A study found that adherence to weight monitoring (OR=0.42; IC 95\% $0.23-0.76 ; p<0.01)$ and diuretic adjustment $(O R=0.44$, $95 \% 0.19-0.98 ; p<0.05)$ reduce the chances of seeking emergency services and hospitalization, which may reduce the morbidity of $\mathrm{HF}^{(13)}$.

The literature reveals improvement in the behavior of adherence to weight control after interventions conducted by nurses in HF outpatient clinics ${ }^{(17)}$. Therefore, the incentive to check the weight is considered relevant in outpatient visits as a measure to encourage patients to incorporate this control in everyday life, understanding that sudden weight gain may indicate an early sign of HF decompensation ${ }^{(17)}$.

Patients with HF perceived fewer barriers and more benefits in relation to self-monitoring of weight and edema. These results are consistent with a previous study that showed a similar mean age ${ }^{(4)}$. Although patients perceive that adherence to this behavior could keep them healthy, improve their quality of life and decrease the chances of readmission, almost half $(46.7 \%)$ reported forgetting that measure.

Apart from the act of forgetting, the most frequently barriers reported by patients to adherence to control of weight and edema were: lack of scales in the household and considering unpleasant to check the swelling of feet and legs. In the literature, the motivation and lack of knowledge about the need for weight control are also mentioned as causes of poor adherence ${ }^{(12,15-16)}$.
The act of forgetting stands out due to the importance it assumes as a barrier ${ }^{(4)}$ and evidence of a significant association between HF and cognitive impairment, such as reduced attention performance and difficulty to concentrate ${ }^{(18)}$. The cognitive dysfunction is prevalent among the elderly ${ }^{(19)}$ and may be responsible for non-adherence rates, especially when changes related to treatment are frequent ${ }^{(11,20)}$. The findings point to the importance of developing strategies to minimize forgetfulness, which may contribute to the reduction of barriers to control of weight and edema.

The association of sociodemographic and clinical variables with barriers to adherence to control of weight and edema is another highlight. Women perceived more barriers to this self-care. Moreover, the lower the educational level and the number of comorbidities, the more the patient perceives checking the weight and edema as a barrier. Therefore it is relevant to implement educational activities that include specific strategies to enhance the benefits of this measure, especially in patients with low education and less comorbidities.

The contribution of this study concerns the influence of the weight control variable on the perceived barriers to adherence. Patients who reported checking their weight once a month were 6.6 times more likely to perceive checking the weight and edema as a barrier, which shows non-adherence to this behavior.

The daily weight control is an important measure directly related to fluid retention and effectiveness of the prescribed dose of diuretics. The sudden weight gain is often associated with water retention and consequently, to worsening of HF. However, patients have difficulty in relating the sudden weight increase with worsening of the clinical picture ${ }^{(11)}$, what constitutes a barrier to adherence to daily weight control. The main difficulty is related to the lack of knowledge and ability to associate a learnt fact to the result of a behavior ${ }^{(5)}$ and patients tolerance for signs of decompensation ${ }^{(21)}$. Thus, the patients' understanding of what should be done in face of a sudden weight gain or worsening of symptoms is more relevant than adherence strategies related to daily weight control ${ }^{(11)}$.

The guidelines for HF recommend that patients are informed about the importance of daily weight control and, in the event of a sudden increase, seek care in emergency departments $^{(6)}$.

The disease management programs have been conducted to facilitate patients' understanding about the treatment through the implementation of strategies to improve adherence and disease management. A study carried out by nurses with HF patients showed that subjects in the intervention group who received intensive guidance on adherence to non-pharmacological measures identified and sought treatment when in presence of a sudden weight gain, compared to the control group which
Factors associated with beliefs about adherence to nonpharmacological treatment of patients with heart failure Saccomann ICRS, Cintra FA, Gallani MCBJ 
received only orientations during consultation with a cardiologist (86 and 69\%, respectively, $\mathrm{p}<0.01)^{(22)}$.

In summary, the health education programs that use strategies to identify the benefits and barriers to self-care contribute to the understanding that the daily checking of weight and edema (easily obtainable measure) can alert the patient for signs of HF decompensation and avoid hospitalization. This measure provides an important contribution to the quality of life of these patients.

\section{Limitation of the study}

The main limitation of this study was regarding the lack of a multidisciplinary team for the management of patients with HF, which may have contributed to poor adherence to control of weight and edema. The presence of a multidisciplinary team that adopts educational strategies has positive impact on the self-care behavior.

\section{REFERENCES}

1. Go AS, Mozaffarian D, Roger VL, Benjamin EJ, Berry JD, Borden WB, et al. Heart disease and stroke statistics - 2013 update: a report from the American Heart Association. Circulation. 2013;127(1):e6-e245.

2. Rabelo ER, Aliti GB, Domingues FB, Ruschel KB, Brun AO, Gonzalez SB. Impact of nursing systematic education on disease knowledge and self-care at a heart failure clinic in Brazil: prospective an interventional study. Online Braz J Nurs [Internet]. 2007 [cited 2013 May 17];6(3). Available from: http://www.objnursing.uff.br/index.php/nursing/article/view/1039

3. Powell LH, Calvin JE Jr, Richardson D, Janssen I, Leon CFM, Flynn KJ, et al. Self-management counseling in patients with heart failure. JAMA. 2010;304(12):1331-8.

4. Van der Wal MHL, Jaarsma T, Moser DK, Van der Gilst WH, Van Veldhuisen. Unraveling the mechanisms for heart failure patient's beliefs about compliance. Heart Lung. 2007;36(4):253-61.

5. Chaudhry SI, Wang Y, Concato J, Gill TM, Krumholz HM. Patterns of weight change preceding hospitalization for heart failure. Circulation. 2007;116(14):1549-54.

6. Jessup M, Abraham WT, Casey DE, Feldman AM, Francis GS, Ganiats TG, et al. 2009 Focused update: ACCF/AHA Guidelines for the Diagnosis and Management of Heart Failure in Adults: a report of the American College of Cardiology Foundation/American Heart Association Task Force on Practice Guidelines Developed in Collaboration with the International Society for Heart and Lung Transplantation. Circulation. 2009;119(14):1977-2016.

\section{CONCLUSION}

This study with HF patients showed that weight control was the main factor related to perceived barriers to adherence to non-pharmacological measures and consequently, the low frequency of weight control. A great part (47.6\%) of patients with HF controlled their weight only once a month, justified by barriers identified as unpleasant and because of forgetting.

The implementation of strategies focused on lowering barriers and increasing the benefits of self-monitoring of weight and edema remain a challenge to health professionals. Educational approaches that involve patients and their families with self-care, allowing them to expose their barriers, questions and experiences can be an important measure to minimize non-adherence.

7. Bocchi EA, Marcondes-Braga FG, Bacal F, Ferraz AS, Albuquerque $D$, Rodrigues D, et al.; Sociedade Brasileira de Cardiologia. Atualização da Diretriz Brasileira de Insuficiência Cardíaca Crônica - 2012. Arq Bras Cardiol. 2012;98(1 Supl.1):1-33.

8. Linhares JC, Aliti GB, Castro RA, Rabelo ER. Prescribing and conducting non pharmacological management of patients with decompensated heart failure admitted to a university hospital emergency. Rev Latino Am Enferm. 2010;18(6):1145-51.

9. Bennett SJ, Perkins SM, Lane KA, Forthofer MA, Brater C, Murray MD. Reliability and validity of the compliance belief scales among patients with heart failure. Heart Lung. 2001;30(3):177-85.

10. Ferreira MC, Gallani MC. Adaptação transcultural dos instrumentos: BMCS-Beliefs about Medication Compliance Scale e BDCS-Beliefs about Dietary Compliance Scale [abstract]. Rev SOCESP. 2005;15 Supl 13:116.

11. Van der Wal MHL, Jaarsma T, Moser DK, Van Gilst WH, Van Veldhuisen DJ. Compliance in heart failure patients: the importance of knowledge and beliefs. Eur Heart J. 2006;27(4):434-40.

12. Ruf V, Stewart S, Pretorius S, Kubheka M, Lautenschläger $C$, Presek $\mathrm{P}$, et al. Medication adherence, self-care behaviour and knowledge on heart failure in urban South Africa: the Heart of Soweto study. Cardiovasc J Afr. 2010;21(2):86-92.

13. Jones CD, Holmes GM, Dewalt DA, Erman B, Broucksou K, Hawk $V$, et al. Is adherence to weight monitoring or weightbased diuretic self-adjustment associated with fewer heart failure-related emergency department visits or hospitalizations? J Card Fail. 2012;18(7):576-84. 
14. Van der Wal MH, Jaarsma T, Van Veldhuisen DJ. Non-compliance in patients with heart failure: how can we manage it? Eur J Heart Fail. 2005;7(1):5-17.

15. Holst M, Willenheimer R, Martensson J, Lindholm M, Strömberg A. Telephone follow-up of self-care behavior after a single session education of patients with heart failure in primary health care. J Cardiovasc Nurs. 2007;6(2):157-9.

16. Linhares JC, Aliti GB, Castro RA, Rabelo ER. Prescribing and conducting non-pharmacological management of patients with decompensated heart failure admitted to a University Hospital Emergency. Rev Latino Am Enferm. 2010;18(6):1145-51.

17. Van der Wal MH, Jaarsma T. Adherence in heart falilure elderly: problem and possible solutions. Int J Cardiol. 2008;125(2):203-8.

18. Alosco ML, Spitznagel MB, van Dulmen M, Raz N, Cohen $\mathrm{R}$, Sweet $\mathrm{LH}$, et al. Cognitive function and treatment adherence in older adults with heart failure. Psychosom Med. 2012;74(9):965-73.
19. Zuccala G, Marzetti E, Cesari M, Monaco MR, Antonica L, Cocchi $A$, et al. Correlates of cognitive impairment among patients with heart failure: results of a multicenter survey. Am J Med. 2005;118(5):496-502.

20. Loyola Filho Al, Uchoa E, Firmo JOA, Lima-Costa MF. Influência da renda na associação entre disfunção cognitiva e polifarmácia: Projeto Bambuí. Rev Saúde Pública. 2008;42(1):89-99.

21. Margoto G, Colombo RCR, Gallani MCBJ. Clinical and psycossocial features of heart failure patients admitted for clinical decompensation. Rev Esc Enferm USP [Internet]. 2009 [cited 2012 Nov 23]:43(1):44-53. Available from: http://www. scielo.br/pdf/reeusp/v43n1/en_06.pdf

22. Van der Wal MH, Jaarsma T. Nurse-led intervention can improve adherence to non-pharmacological treatment in heart failure patients (Data from the $\mathrm{COACH}$ study) [abstract]. Eur J Cardiovas Nurs. 2008;7 Suppl 1:S41. 